\title{
Economic Growth and Environmental Sustainability in Thailand
}

\author{
Suad Abubakar Hassan \\ Department of Economics in SIMAD universuty, Mogadishu, Somalia
}

\begin{abstract}
In this study we aim to study the relationship between economic growth and environmental sustainability in Thailand with observations of variables extending a decade between 2000-2010 in this study we'll look into the long run relationship between economic growth and environment. In the literature the question of how economic activities effect environment have been studied from many angles, but the results are different simply due to scholar's diverse measures of impact on nature.The main contribution of this study adding to the comparison between pollution measures and eco-efficiency measures, The study has revealed that while GDP per capita have positive relationship with improving water quality availability and biodiversity in terms of national reserved areas, it also has positive relationship with forest depilation which stands for Product of net resource rents, and excess of round wood harvest over natural growth
\end{abstract}

Keywords: Economic growth, Environmental sustainability, EKC curve in Thailand

DOI: $10.7176 / \mathrm{JESD} / 10-16-05$

Publication date: August $31^{\text {st }} 2019$

\section{Introduction}

Thailand became an upper-middle income economy in 2011. Over the last four decades, Thailand has made remarkable progress in social and economic development, moving from a low-income country to an upper-income country in less than a generation. Since 2005 the government has embarked on an ambitious reform program to raise Thailand's long-term growth path and achieve high-income status.

Thailand has been one of the widely cited development success stories, with sustained strong growth and impressive poverty reduction.

In this study we aim to study the relationship between economic growth and environmental sustainability in Thailand with observations of variables extending a decade between 2000-2010 in this study we'll look into the long run relationship between economic growth and environment, using theoretical and empirical literature that are related to the topic on hand, then we'll test our own data and from there conclusions will be drawn.

Although there is no fully developed measure to measure interaction between economic growth and environmental degradation, there were many attempts made over the years among them the "ecological footprint index" and the natural disinvestment components of adjusted net savings (ANS) are worth mentioning.

There are plenty of studies done on economic and environmental sustainability that relate to current sudy, to mention few the "the relationship between economic growth and environmental pollution: Zhejiang province"by Yang, Yuan and Sun, and "the impact of economic growth on environmental conditions in Laos"by HattachanPhimphanthavong.

This study contributes to the literature on economic growth and relationship with environment and the existence of Environmental Kuznets Curve (EKC) in Thailand

This study is significant because it adds to the debate on given the natural environment's absorbing limit of waste produced from economic systems, will the continued growth ultimately lead to more damage to region, country and global environment or will it help to improve the quality of environment?

\section{Framework.}

\subsection{The economic theory}

The relationship between economic and environment is controversial. Traditional economic theory posts a tradeoff between economic growth and environmental quality, however since early 1990s the increasing theoretical and empirical literature on Environmental Kuznets Curve (EKC) argues that the relationship between economic growth and environment could be positive and hence growth is important to environmental improvement.

\subsection{Literature review}

In the literature the question of how economic activities effect environment have been studied from many angles, but the results are different simply due to scholar's diverse measures of impact on nature.

A number of studies have been summarized as follows: 
Table 1. Literature review

\begin{tabular}{|c|c|c|c|}
\hline Title & Author & Data and country & Results and findings \\
\hline $\begin{array}{l}\text { *On the relationship } \\
\text { between economic } \\
\text { growth and } \\
\text { environmental } \\
\text { sustainability }\end{array}$ & $\begin{array}{l}\text { Lee Hyun-hoon } \\
\text { Rae kwon } \\
\text { Chung } \\
\text { Chung Mo koo }\end{array}$ & $\begin{array}{l}\text { Cross section data of } 11 \text { ESI } \\
\text { indicators collected from } \\
140 \text { countries in } 2003\end{array}$ & $\begin{array}{l}>\text { While income has beneficial on } \\
\text { pollution measures, it has } \\
\text { detrimental effect on eco- } \\
\text { efficiency measures of } \\
\text { environmental sustainability }\end{array}$ \\
\hline $\begin{array}{l}\text { *Economic growth and } \\
\text { its impact on } \\
\text { environment: a panel } \\
\text { data analysis }\end{array}$ & AhmetAtilAsici & $\begin{array}{l}\text { Panel data consisting of } 213 \\
\text { high, middle and low } \\
\text { income countries }\end{array}$ & $\begin{array}{l}\text { >There is positive relationship } \\
\text { between income and pressure on } \\
\text { nature, however the effect is } \\
\text { stronger in middle-income } \\
\text { countries than in low and high- } \\
\text { income countries }\end{array}$ \\
\hline $\begin{array}{l}\text { *Relationship between } \\
\text { environment and } \\
\text { sustainable economic } \\
\text { development: } \\
\text { theoretical approach to } \\
\text { environmental } \\
\text { problems }\end{array}$ & $\begin{array}{l}\text { Abdul } \\
\text { GhafoorAwan }\end{array}$ & $\begin{array}{l}\text { Descriptive study also trend } \\
\text { and content analysis on } \\
\text { secondary data collected } \\
\text { from both developed and } \\
\text { developing countries }\end{array}$ & $\begin{array}{l}\text { >Both developed and developing } \\
\text { countries are causing hazards on } \\
\text { nature. Developed countries are } \\
\text { using excessive resources for } \\
\text { export, while poor countries are } \\
\text { exploiting their resources to feed } \\
\text { growing population and end } \\
\text { poverty level }\end{array}$ \\
\hline $\begin{array}{l}\text { *The impacts of } \\
\text { economic growth on } \\
\text { environmental } \\
\text { conditions in Laos }\end{array}$ & $\begin{array}{l}\text { HattachanPhimp } \\
\text { hanthavong }\end{array}$ & $\begin{array}{l}\text { Time series data between } \\
1980 \text { and } 2010, \text { this study is } \\
\text { based on Environmental } \\
\text { Kuznets Curve hypothesis }\end{array}$ & $\begin{array}{l}>\text { Correlation between economic } \\
\text { growth and environmental } \\
\text { degradation, along with trade } \\
\text { openness, industrial extension } \\
\text { and becoming an ASEAN } \\
\text { member }\end{array}$ \\
\hline $\begin{array}{l}\text { *The relationship } \\
\text { between economic } \\
\text { growth and } \\
\text { environmental } \\
\text { pollution: a Zhejiang } \\
\text { province study }\end{array}$ & $\begin{array}{l}\text { Lixia Yang } \\
\text { Shaofeng Yuan } \\
\text { Le Sun }\end{array}$ & $\begin{array}{l}\text { Investigates the interactions } \\
\text { of environmental pollution } \\
\text { and economic growth in } \\
\text { Zhejiang province } \\
\text { according to pollution } \\
\text { indices data from 1981- } \\
2006\end{array}$ & $\begin{array}{l}\text { >Although GDP per capita has } \\
\text { long term cointegration } \\
\text { relationship with pollution } \\
\text { indices, GDP per capita granger } \\
\text { caused pollution emission of } \\
\text { industrial gas and water waste, } \\
\text { except for solid waste discharge }\end{array}$ \\
\hline
\end{tabular}

\subsection{Model specification}

We'll use as dependent variable each of forest depletion, biodiversity and water quality, and the reason is water quality is used as proxy for pollution measure, while forest depletion and biodiversity are among the eco-efficiency measures of environmental sustainability discussed in 2014 Environmental Performance Index EPI report.

GDP per capita is the main explanatory variable to measure the general relationship between income and measures of environmental sustainability, according to EKC income growth over period has beneficial effect on pollution reduction, however some studies suggest that GDP per capita has negative relationship with most of environmental sustainability measures, so the expected result could be positive or negative.

In addition a control variable is included which is population density, this is included because higher population tends to lead to environmental degradation given the level of per capita income.

The final model form is like following:

ES: environmental sustainability

$$
E S_{t}=\beta_{0}+\beta_{1} \mathrm{GDPC}+\beta_{2} \mathrm{POP}+\varepsilon_{t}
$$

GDPC: GDP per capita

POP: population density

$\boldsymbol{\varepsilon}$ : Error term

t: Thailand observations over 200-2010 time period 


\section{Data}

Table 2. Data sources and description

\begin{tabular}{|l|l|l|}
\hline Variable & Description & Source \\
\hline $\begin{array}{l}\text { Water quality } \\
\text { (WTR) }\end{array}$ & $\begin{array}{l}\text { Percentage of population with access to } \\
\text { improved drinking water source }\end{array}$ & $\begin{array}{l}\text { WHO/UNICEF Joint Monitoring } \\
\text { Programme (JMP) for Water Supply and } \\
\text { Sanitation, 2013 }\end{array}$ \\
\hline $\begin{array}{l}\text { GDP per capita } \\
\text { (GDPC) }\end{array}$ & $\begin{array}{l}\text { Gross domestic product (US\$) divided by } \\
\text { midyear population }\end{array}$ & World bank database NY.GDP.PCAP.CD \\
\hline $\begin{array}{l}\text { Net Forest } \\
\text { depletion (FRST) }\end{array}$ & $\begin{array}{l}\text { Product of net resource rents, and excess } \\
\text { of round wood harvest over natural growth }\end{array}$ & WDI online data base \\
\hline $\begin{array}{l}\text { Population } \\
\text { density (POP) }\end{array}$ & Total population by land area $\mathrm{km}^{2}$ & WDI online database \\
\hline $\begin{array}{l}\text { Biodiversity } \\
\text { (BIOD) }\end{array}$ & $\begin{array}{l}\text { Percentage of protected terrestrial biomes } \\
\text { weighted by national level }\end{array}$ & $\begin{array}{l}\text { IUCN and UNEP-WCMC. (2013). The } \\
\text { World Database on Protected Areas } \\
\text { (WDPA) }\end{array}$ \\
\hline
\end{tabular}

It should be noted that EPI is a composite index which includes 31 indicators of environment measures, and in this study only 3 indicators are included, the other variable are excluded because they are social issue relate or too broad to measure of technology and governance system.

The scope of data is decade and although it's small it was chosen because of steady data availability and no missing data in between, it's expected this sample size may cause somewhat adequate yet little bit divert from expected results.

The data also exhibits steady growth of the main variables, except for forest depletion which seems to have fluctuations over the observed period

\section{$\mathrm{BIOD}$}

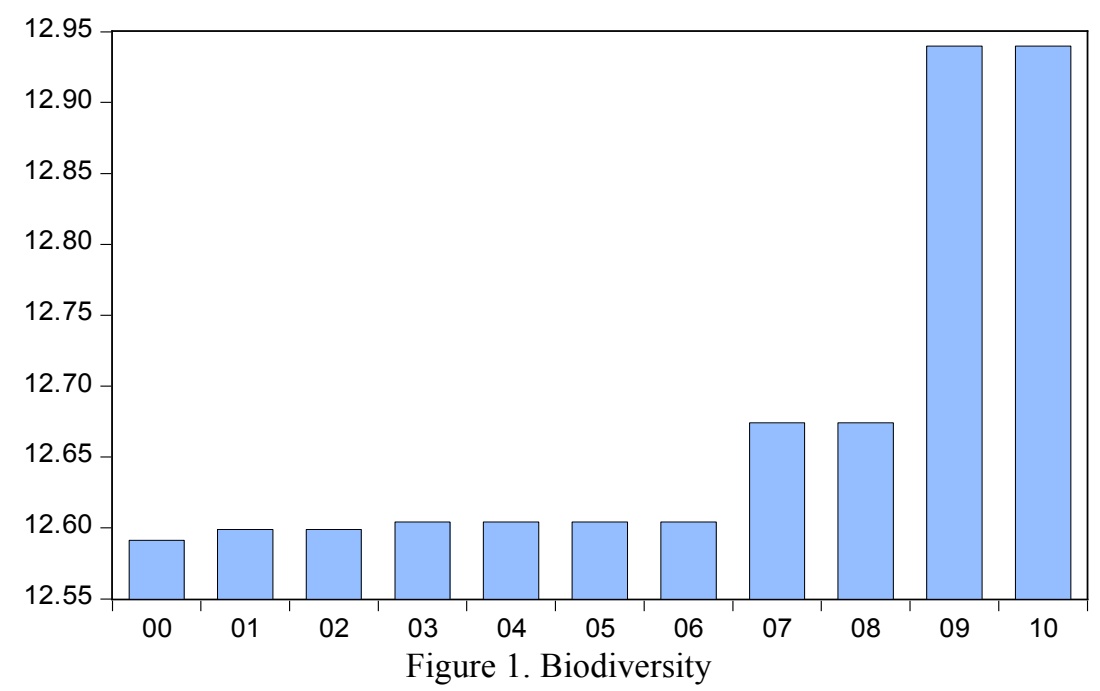

GDPC

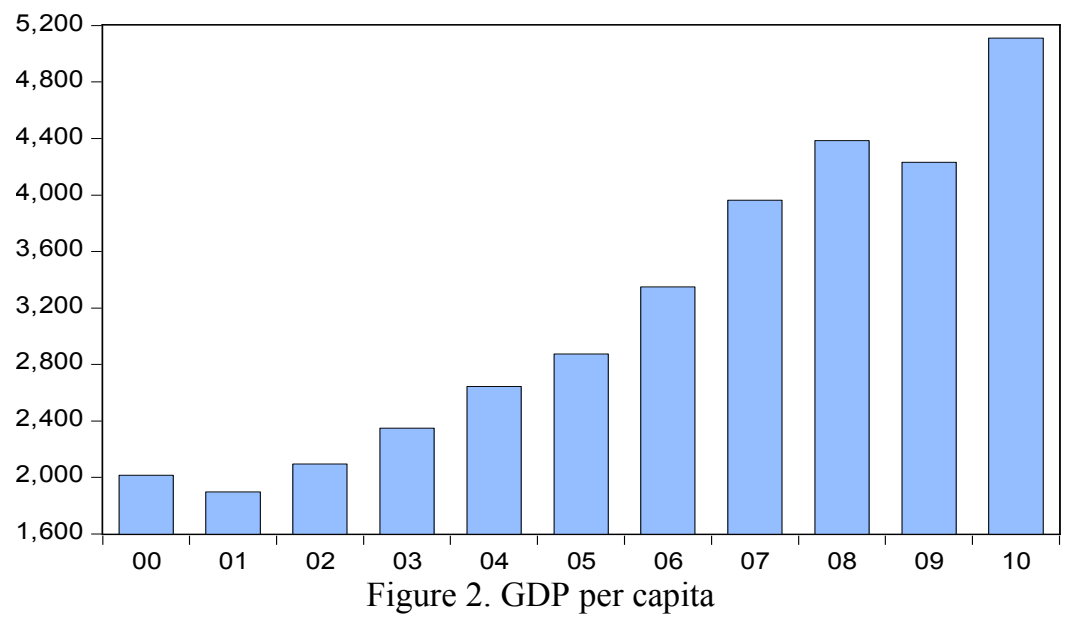




\section{WTR}

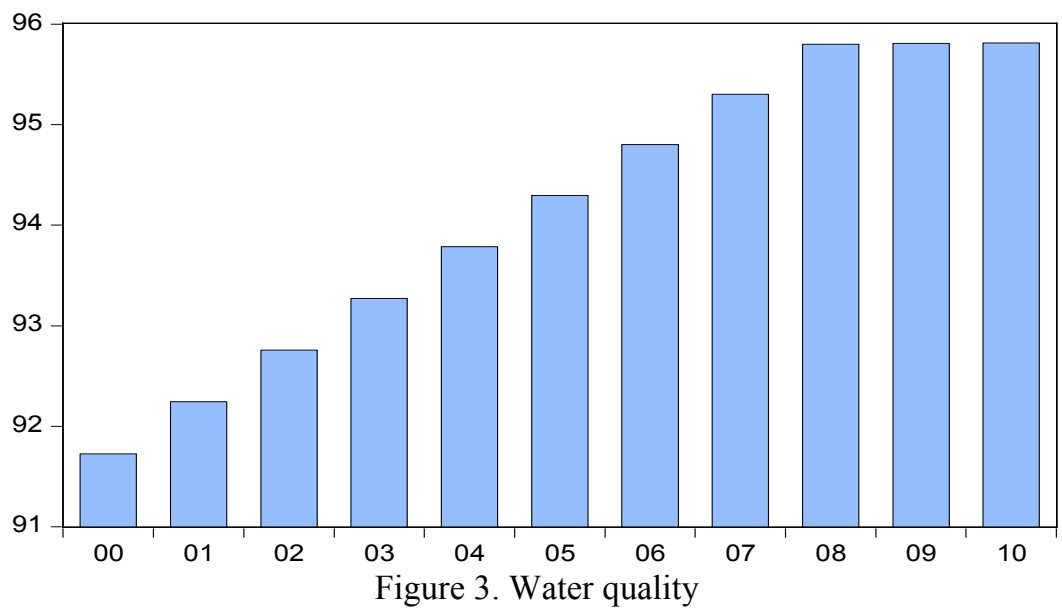

FRST

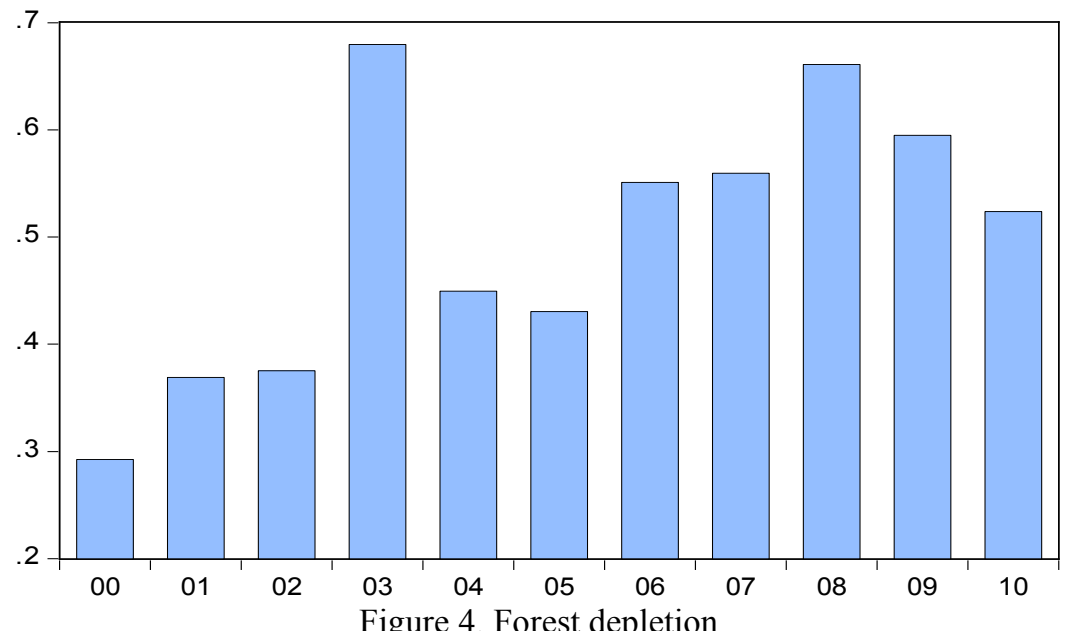

The data also shows a correlation among the variables:

Table 3. General correlation between variables

\begin{tabular}{cccccc}
\hline & FRST & GDPC & POP & WTR & BIOD \\
FRST & 1.000000 & & & & \\
GDPC & 0.607017 & 1.000000 & & & \\
POP & 0.722670 & 0.872223 & 1.000000 & & \\
WTR & 0.716393 & $0.9460^{* *}$ & $0.9748^{* *}$ & 1.000000 & 1.000000 \\
BIOD & $0.35965^{*}$ & 0.794147 & 0.582280 & 0.680849 & \\
\hline
\end{tabular}

NOTE:* denotes weak relationship and, ** denotes strong relationship

This shows that the variables have general positive correlation with each other, population density and water quality have the strongest correlation followed by water quality and GDP per capita, while forest depletion and biodiversity have the weakest correlation which is expected.

\section{Economic results}

4.1Model estimation

First we'll estimate our model, starting with WTR then BIOD and finally FRST, by using OLS method, we'll test for Unit root and do any other necessary diagnostic checking. 


\subsubsection{Dependent Variable: WTR}

Table 4. Unit root test (WTR, POP, GDPC)

Newey-West automatic bandwidth selection and Bartlett kernel

\begin{tabular}{|c|c|c|c|c|}
\hline Method & Statistic & Prob.** & $\begin{array}{l}\text { Cross- } \\
\text { sections }\end{array}$ & Obs \\
\hline \multicolumn{5}{|c|}{ Null: Unit root (assumes common unit root process) } \\
\hline Levin, Lin \& Chu t* & -21.6208 & 0.0000 & 3 & 28 \\
\hline Breitung t-stat & 0.21693 & 0.5859 & 3 & 25 \\
\hline \multicolumn{5}{|c|}{ Null: Unit root (assumes individual unit root process) } \\
\hline Im, Pesaran and Shin W-stat & -4.87757 & 0.0000 & 3 & 28 \\
\hline ADF - Fisher Chi-square & 21.1827 & 0.0017 & 3 & 28 \\
\hline PP - Fisher Chi-square & 7.17961 & 0.3046 & 3 & 30 \\
\hline
\end{tabular}

** Probabilities for Fisher tests are computed using an asymptotic Chi -square distribution. All other tests assume asymptotic normality.

Null hypothesis of unit root is rejected by 3 of the 5 total tests on unit root, which means that or data suffers from neither inconstant mean, variance nor covariance, in other words the data is stationary.

Table 5. OLS coefficient estimation

\begin{tabular}{lllll} 
Variable & Coefficient & Std. Error & t-Statistic & Prob. \\
\hline \hline C & 48.02897 & 5.173277 & 9.284051 & 0.0000 \\
GDPC & 0.000542 & 0.000104 & 5.201061 & 0.0008 \\
POP & 0.347218 & 0.042696 & 8.132414 & 0.0000 \\
\hline \hline R-squared & 0.988668 & Mean dependent var & 94.14574 \\
Adjusted R-squared & 0.985835 & S.D. dependent var & 1.495345 \\
S.E. of regression & 0.177971 & Akaike info criterion & -0.387388 \\
Sum squared resid & 0.253390 & Schwarz criterion & -0.278871 \\
Log likelihood & 5.130632 & Hannan-Quinn criter. & -0.455792 \\
F-statistic & 348.9821 & Durbin-Watson stat & 1.582130 \\
Prob(F-statistic) & 0.000000 & & \\
\hline \hline
\end{tabular}

Table 6. Residual Diagnostic tests:

Heteroskedasticity Test: White

\begin{tabular}{llll}
\hline \hline F-statistic & 6.256906 & Prob. F(5,5) & 0.0328 \\
Obs*R-squared & 9.484202 & Prob. Chi-Square(5) & 0.0912 \\
Scaled explained SS & 4.989871 & Prob. Chi-Square(5) & 0.4171 \\
\hline \hline Breusch-Godfrey Serial Correlation LM Test: & \\
\hline \hline F-statistic & 1.982113 & Prob. F(3,5) & 0.2352 \\
Obs*R-squared & 5.975489 & Prob. Chi-Square(3) & 0.1128 \\
\hline \hline
\end{tabular}

Interpretation for WTR

After confirming the data is stationary we proceeded to estimation, the R-square is 0.98 or $98 \%$ of the model is explained by independent variables, which fairly good, both GDPC and POP have positive coefficients of 0.00054 and 0.35 respectively. In the residual diagnostic checking, neither heteroscedasticity nor serial correlation were found, so our data doesn't suffer from statistical problems.

4.1.2 Dependent Variable: BIOD

Null hypothesis of unit root is rejected by 3 tests (Levin, Lin \& Chu, Im, Pesaran and Shin W-stat and ADF Fisher Chi-square) of the 5 total tests on unit root, which means that or data don't suffer from neither inconstant mean, variance nor covariance, in other words the data is stationary. 
Table 7. Unit root test (BIOD, GDPC, POP)

Newey-West automatic bandwidth selection and Bartlett kernel

\begin{tabular}{lcclc}
\hline \hline & & & \multicolumn{2}{c}{ Cross- } \\
Method & Statistic & Prob.** & sections & Obs \\
\hline Null: Unit root (assumes common unit root process) & & \\
\hline Levin, Lin \& Chu t* & -15.5113 & 0.0000 & 3 & 28 \\
Breitung t-stat & 0.07705 & 0.5307 & 3 & 25 \\
Null: Unit root (assumes individual unit root process) & & \\
\hline Im, Pesaran and Shin W-stat & -4.01232 & 0.0000 & 3 & 28 \\
ADF - Fisher Chi-square & 21.1827 & 0.0017 & 3 & 28 \\
PP - Fisher Chi-square & 7.50112 & 0.2770 & 3 & 30 \\
\hline \hline
\end{tabular}

** Probabilities for Fisher tests are computed using an asymptotic Chi -square distribution. All other tests assume asymptotic normality.

Table 8. OLS coefficient estimation

\begin{tabular}{ccccc}
\hline Variable & Coefficient & Std. Error & t-Statistic & Prob. \\
\hline \hline GDPC & 0.000145 & $4.94 \mathrm{E}-05$ & 2.933821 & 0.0189 \\
POP & -0.022903 & 0.020244 & -1.131356 & 0.2907 \\
C & 15.14396 & 2.452883 & 6.173944 & 0.0003 \\
\hline \hline R-squared & 0.681610 & Mean dependent var & 12.67588 \\
Adjusted R-squared & 0.602013 & S.D. dependent var & 0.133760 \\
S.E. of regression & 0.084384 & Akaike info criterion & -1.879872 \\
Sum squared resid & 0.056966 & Schwarz criterion & -1.771355 \\
Log likelihood & 13.33930 & Hannan-Quinn criter. & -1.948277 \\
F-statistic & 8.563220 & Durbin-Watson stat & 1.935221 \\
Prob(F-statistic) & 0.010276 & & \\
\hline
\end{tabular}

Table 9. Residual diagnostic tests

Heteroskedasticity Test: White

\begin{tabular}{llll}
\hline \hline F-statistic & 1.876618 & Prob. F(5,5) & 0.2532 \\
Obs*R-squared & 7.176065 & Prob. Chi-Square(5) & 0.2079 \\
Scaled explained SS & 4.875519 & Prob. Chi-Square(5) & 0.4313 \\
\hline \hline
\end{tabular}

Breusch-Godfrey Serial Correlation LM Test:

\begin{tabular}{llll}
\hline \hline F-statistic & 1.604654 & Prob. F(2,6) & 0.2765 \\
Obs*R-squared & 3.833337 & Prob. Chi-Square(2) & 0.1471
\end{tabular}

\section{Interpretation for BIOD}

After confirming the data is stationary we proceeded to estimation, the R-square is 0.68 or $68 \%$ of the model is explained by independent variables, which fairly good forecasting ability, GDPC has positive coefficient of 0.000145 , while POP has a negative coefficient of -0.0229

In the residual diagnostic checking, neither heteroscedasticity nor serial correlation were found, so our data doesn't suffer from statistical problems

\subsubsection{Dependent Variable: FRST}

Null hypothesis of unit root is rejected by 3 tests (Levin, Lin \& Chu, Im, Pesaran and Shin W-stat and ADF Fisher Chi-square) of the 5 total tests on unit root, which means that or data suffers from neither inconstant mean, variance nor covariance, which means that in other words the data is stationary and we can proceed to the remaining analysis steps. 
Table 10. Unit root test (FRST, GDPC, POP)

Newey-West automatic bandwidth selection and Bartlett kernel

\begin{tabular}{|c|c|c|c|c|}
\hline Method & Statistic & Prob.** & $\begin{array}{l}\text { Cross- } \\
\text { sections }\end{array}$ & Obs \\
\hline \multicolumn{5}{|c|}{ Null: Unit root (assumes common unit root process) } \\
\hline Levin, Lin \& Chu $\mathrm{t}^{*}$ & -22.7635 & 0.0000 & 3 & 29 \\
\hline Breitung t-stat & -0.19335 & 0.4233 & 3 & 26 \\
\hline \multicolumn{5}{|c|}{ Null: Unit root (assumes individual unit root process) } \\
\hline Im, Pesaran and Shin W-stat & -8.09330 & 0.0000 & 3 & 29 \\
\hline ADF - Fisher Chi-square & 24.3964 & 0.0004 & 3 & 29 \\
\hline PP - Fisher Chi-square & 13.6670 & 0.0336 & 3 & 30 \\
\hline
\end{tabular}

** Probabilities for Fisher tests are computed using an asymptotic Chi -square distribution. All other tests assume asymptotic normality.

Table 11. OLS coefficient estimation:

\begin{tabular}{lllll} 
Variable & Coefficient & Std. Error & t-Statistic & \multirow{2}{*}{ Prob. } \\
\hline \hline GDPC & $6.89 \mathrm{E}-05$ & $3.01 \mathrm{E}-05$ & 2.291529 & 0.0477 \\
$\mathrm{C}$ & 0.280069 & 0.100577 & 2.784608 & 0.0212 \\
\hline \hline R-squared & 0.368470 & Mean dependent var & 0.498835 \\
Adjusted R-squared & 0.298300 & S.D. dependent var & 0.125316 \\
S.E. of regression & 0.104974 & Akaike info criterion & -1.507245 \\
Sum squared resid & 0.099176 & Schwarz criterion & -1.434900 \\
Log likelihood & 10.28985 & Hannan-Quinn criter. & -1.552848 \\
F-statistic & 5.251104 & Durbin-Watson stat & 1.893129 \\
Prob(F-statistic) & 0.047655 & &
\end{tabular}

Table 12. Residual diagnostic tests:

HeteroskedasticityTest: White

\begin{tabular}{llll}
\hline \hline F-statistic & 0.329021 & Prob. F(2,8) & 0.7289 \\
Obs*R-squared & 0.836039 & Prob. Chi-Square(2) & 0.6583 \\
Scaled explained SS & 0.857791 & Prob. Chi-Square(2) & 0.6512 \\
\multicolumn{2}{l}{ Breusch-Godfrey Serial Correlation LM Test: } & \\
\hline \hline F-statistic & 0.273996 & Prob. F(2,7) & 0.7681 \\
Obs*R-squared & 0.798612 & Prob. Chi-Square(2) & 0.6708
\end{tabular}

To test whether POP have effect on FRST we use restriction test Table 13. Wald Test:

FRST and POP

\begin{tabular}{llcc}
\hline \hline Test Statistic & Value & df & Probability \\
\hline \hline t-statistic & 2.114266 & 8 & 0.0674 \\
F-statistic & 4.470119 & $(1,8)$ & 0.0674 \\
Chi-square & 4.470119 & 1 & 0.0345
\end{tabular}

\section{Interpretation for FRST}

After confirming the data is stationary we proceeded to estimation, the R-square is 0.368 or $36 \%$ of the model is explained by independent variables, which fairly good forecasting ability, both GDPC have positive coefficient of6.89, Although R-square is small, in the residual diagnostic checking, neither heteroscedasticity nor serial correlations were found, so our data doesn't suffer from statistical problems.

And whether population density have effect on forest depilation or not, we found that $p$-value is 0.06 which is greater than 0.05 , that means null hypothesis is failed to reject and population density have no effect on forest 
depilation.

\section{Conclusion}

Maintaining environmental sustainability is not only limited to reducing pollution but also to guarantee ecoefficiency standards. Environmental sustainability is ensuring the needs of the present generation without compromising environmental carrying capacity for the future generation

Environmental issues are very complicated because it has trade off between economic growth and environment, higher economic growth means higher results in higher resources exploitation regardless of the everlasting impacts of future generations, the difficulty of maintaining balance between economic growth and environmental degradation is difficult task for developing countries which have been striving for economic growth for so long.

The main contribution of this study is adding to the comparison between pollution measures and ecoefficiency measures

The study has revealed that while GDP per capita have positive relationship with improving water quality availability and biodiversity in terms of national reserved areas, it also has positive relationship with forest depilation which stands for Product of net resource rents, and excess of round wood harvest over natural growth. Population density was also found to have no effect on forest depelation; this could be due to peoples' tendency to populate urban areas rather than rural areas, thus no effect on forest.

The results are not consistent with the predictions of EKC hypothesis, although it agrees with beneficial effect of income on water quality and biodiversity it also suggests that only pollution measures may improve with income and not all environmental policies. This also implies that pollution control policies need to be combined with ecoefficiency options to improve environmental quality, otherwise economic growth will continue to degrade nature in the future.

So instead of waiting for market forces to react or technology and institutional structure to develop, more radical steps must be taken to decrease the pressure on nature.

More extensions and improvements could be made in this topic, for example a larger sample and more indicators can be added for further work.

\section{References}

Asici, A. A. (2011). Economic growth and its impact on environment: a panel data analysis. Istanbul.

Awan, A. (2013). Relationship between environment and sustainable economic development: theoretical approach to environmental problems. Multan-Pakistan.

Lee, H., Rae, k., \& Chung, M. (2010). On the relationship between economic growth and environmental sustainability. Seoul .

Phimphanthavong, H. (2013). The impacts of economic growth on environmental conditions in Laos. Trento.

Yang, L., Yuan, S., \& Sun, L. (2011). *The relationship between economic growth and environmental pollution: a Zhejiang province study.

WHO/UNICEF Joint Monitoring Programme (JMP) for Water Supply and Sanitation, 2013

World bank database NY.GDP.PCAP.CD

WDI online data base

IUCN and UNEP-WCMC. (2013). The World Database on Protected Areas (WDPA) 